\title{
PHẪU THUẬT NộI SOI VÁ THÔNG LIÊN THẤT QUA ĐƯờnG MỞ NGỰC NHỎ
}

\author{
Đặng Quang Huy*, Nguyễn Công Hưu*, Trần Đắc Đại*,Nguyễn Thế Bìn *, \\ Nguyễn Văn Huynh*, Đỗ Văn Tu*, Phạm Ngoc Anh*, Lê Ngọ Thành*
}

\section{TÓM TẮT}

Thời gian gần đây bên cạnh chất lượng cuộc mổ, người bệnh mổ tim dành ngày càng nhiều sự quan tâm tới yếu tố thẩm mỹ. Từ tháng $6 / 2015$ đến tháng 6/2016, 15 bệnh nhân từ 3 tuổi trở lên (nam/nữ: 10/5) được phẫu thuật đóng lỗ thông liên thất (TLT) qua đường mở ngực nhỏ trước bên bên phải $(n=8)$ và bên trái $(n=7)$. Chúng tôi so sánh những thông số liên quan cuộc mổ của những bệnh nhân này với những bệnh nhân có cùng độ tuổi $(n=25)$ được phẫu thuật đóng lỗ thông liên thất trong khoảng thời gian trước đó.Trong nhóm mở ngực nhỏ, các lỗ thông liên thất bao gồm: quanh màng $(n=6)$ và dưới các đại động mạch $(n=9)$. Thời gian theo dõi sau mổ từ 1 tháng đến 1 năm. Không có trường hợp nào tử vong trong thời gian theo dõi. Thời gian chạy máy và thời gian cặp động mạch chủ của nhóm mở ngực nhỏ dài hơn so với nhóm cưa xương ức. Tất cả lỗ thông được đóng kín, 2 trường hợp hẹp nhẹ đường ra thất phải sau mổ qua đường mở ngực trái, chênh áp giảm sau thời gian theo dõi, không có biến chứng liên quan tới thiết lập tuần hoàn ngoại vi. Không có sự khác biệt về thời gian thở máy, thời gian nằm hồi sức và thời gian nằm viện sau mổgiữahai nhóm. Bệnh nhân trong nhóm mở ngực nhỏ có mức độ hài lòng cao về vị trí và kích thước sẹo mổ và chất lượng cuộc sống sau mổ. Phẫu thuật tim ít xâm lấn qua đường mở ngực nhỏ an toàn và hiệu quả trong điều trị đóng thông liên thất ở trẻ lớn và người trưởng thành.

Từ khóa: phẫu thuật tim ít xâm lấn, mở ngực nhỏ trước bên, bệnh thông liên thất

\section{Right and left anterolateral mini-thoracotomy for repair of congenital ventricular septal defect}

\section{SUMMARY}

Much more concern is recently paid to the cosmetic when simple congenital heart disease (CHD) is repaired. From June 2015to June 2016, 15 patients (F/M: 5/10; aged from 3 to 50 years) underwent repair of congenital ventricular septal defects (VSDs) using right $(n=8)$ and left $(n=7)$ anterolateral minithoracotomy. We compared the peri-operative data of these patients with that of the same age patients $(n=25)$ who underwent median sternotomy before that time. VSDs were of the peri-membranous $(n=6)$ and sub-arterial infundibular $(n=9)$ type in mini-thoracotomy group. Follow up time was from 1 month to 1 year. There was no in-hospital mortality in both groups. Mean Cardiopulmonary bypass (CPB) time and Aorta cross clamping (ACC) time in two mini-thoracotomy subgroups were longer than that of sternotomy subgroups, respectively. There were no differences between mean intubation time, ICU stay time and postoperative hospital stay time in two minithoracotomy subgroups and that of sternotomy subgroups. Closure of VSDs was successfully performed in all patients. There were no complications related to peripheral cannulation. All the patients and their family were satisfied with cosmetic result of the scars. This method was safe and effective especially for girls and women with VSDs.

Keywords: Minimally invasive cardiac surgery, right anterolateral mini-thoracotomy, ventricular septal defect, pediatric cardiac surgery...

From Department of cardiovascular and thoracic surgery, Cardiovascular center, E hospital, 89

Trancung, Caugiay, Hanoi, Vietnam

\section{I. ĐẶT VẤN ĐỀ}

Thời gian gần đây, phẫu thuật tim ít xâm lấn đã và đang thay thế dần phương pháp mổ kinh điển trong điều trị các bệnh tim bẩm sinh do ưu điểm về vị trí, kích thước sẹo mổ cũng như cho phép bệnh nhân sớm trở lại với sinh hoạt hàng ngày. Phẫu thuật tim ít xâm

\footnotetext{
* Trung tâm Tim mạch Bệnh viện E

Ngươi chịu trách nhiệm khoa họ: GS.TS. Lê Ngoc Thành

Ngày nhận bài: 18/06/2016 - Ngày Cho Phép Đăng: 18/08/2016

Phản Biện Khoa học: PGS.TS. Đặng Ngọc Hùng
}

GS.TS. Bùi Đức Phú 
lấn trong điều trị bệnh thông liên thất có nhiều đường tiếp cận khác nhau: cưa bán phần xương ức, mở ngực nhỏ có nội soi hỗ trợ và phẫu thuật nội soi toàn bộ. Nhiều tác giả như Kadner (2004), Nicholson (2001), Nishigaki (2005)... đã báo cáo kết quả tốt từ việc sử dụng đường đường mổ cưa bán phần xương ức để đóng thông liên thất [1-3].

Sử dụng đường mở ngực nhỏ có nội soi hỗ trợ để đóng lỗ thông liên thất chưa được áp dụng rộng rãi.Jung, S. H., et al. (2010) báo cáo sử dụng đường mở ngực nhỏ trong đóng thông liên thất ở người lớn[4]. Rất ít báo cáo sử dụng đường mổ này trong đóng thông liên thất ở trẻ nhỏđược công bố trên các tạp chí chuyên ngành.Từ đó, chúng tôi báo cáo kinh nghiệm ban đầu về phẫu thuật đóng thông liên thất ở trẻ nhỏ và người trưởng thành sử dụng đường mở ngực trước bên phải và trái.

\section{II. ĐỐI TƯợNG VÀ PHƯƠNG PHÁP NGHIÊN CÚU}

- Đối tượng nghiên cứu:

Từ tháng 6/2015 đến tháng 6/2016, có 15 bệnh nhân từ 3 tuổi trở lên $(9$ bệnh nhân $\leq 18$ tuổi, nam/nữ: 10/5) được phẫu thuật đóng lỗ thông liên thất qua đường mở ngực nhỏ trước bên. Nhóm chứng gồm 25 bệnh nhân có cùng độ tuổi được phẫu thuật đóng lỗ thông liên thất qua cưa toàn bộ xương ức trong khoảng thời gian trước tháng 6/2015.

Trong cả hai nhóm, chúng tôi loại trừ những thông liên thất kèm theo bất thường bẩm sinh khác, mổ lại, viêm nội tâm mạc nhiễm trùng và phình xoang Valsalva. Tất cả bệnh nhân có nhịp xoang trên điện tâm đồ và không có biểu hiện suy tim nặng trước mổ.

\begin{tabular}{|c|c|c|c|}
\hline \multicolumn{4}{|c|}{ Bảng 1. Các thông số nhân trắc học và thông số trước mổ } \\
\hline & Nhóm mở ngực nhỏ (n=15) & $\begin{array}{l}\text { Nhóm cưa toàn bộ xương ức } \\
\qquad(\mathrm{n}=25)\end{array}$ & $\mathrm{P}$ \\
\hline Tuổi (năm) & $17.9 \pm 13.2$ & $11.04 \pm 9.5$ & 0.08 \\
\hline Giới (nam/nữ) & $10: 5$ & $16: 9$ & \\
\hline Cân nặng (kg) & $35.5 \pm 17.1$ & $25.4 \pm 14.7$ & 0.047 \\
\hline Diện tích da $\left(\mathrm{m}^{2}\right)$ & $1.173 \pm 0.399$ & $0.933 \pm 0.36$ & 0.05 \\
\hline \multicolumn{4}{|l|}{ Loại TLT } \\
\hline TLT typ I & 6 & 10 & \\
\hline TLT typ II & 9 & 15 & \\
\hline Đường kính TLT & $9.3 \pm 2.8$ & $8.1 \pm 4.2$ & 0.13 \\
\hline Sử dụng miếng vá (\%) & 100 & 100 & \\
\hline
\end{tabular}

Các thông số nhân trắc học (tuổi, cân nặng, diện tích da, kích thước lỗ thông) trước mổ giữa hai nhóm nghiên cứu và sự khác nhau về vị trí thông liên thất được trình bày trong Bảng 1. Phương pháp phẫu thuật được hội đồng khoa học bệnh viện thông qua và được sự đồng thuận của gia đình bệnh nhân.

\section{- Phương pháp phẫu thuật}

Chúng tôi lựa chọn đường mổ dựa vào vị trí của thông liên thất. Đường mở ngực phải dành cho TLT quanh màng và TLT phần phễu dưới van ĐMC. Đường mở ngực trái dành cho TLT phễu (dưới hai van hoặc dưới van ĐMP). Bệnh nhân được gây mê bằng ống nội khí quản một nòng. Bác sĩ gây mê đặt catheter 
tĩnh mạch trung ương vào $\mathrm{TM}$ cảnh trong trái và đặt sẵn một kim luồn vào $\mathrm{TM}$ cảnh trong phải, tất cả được thực hiện vô trùng.
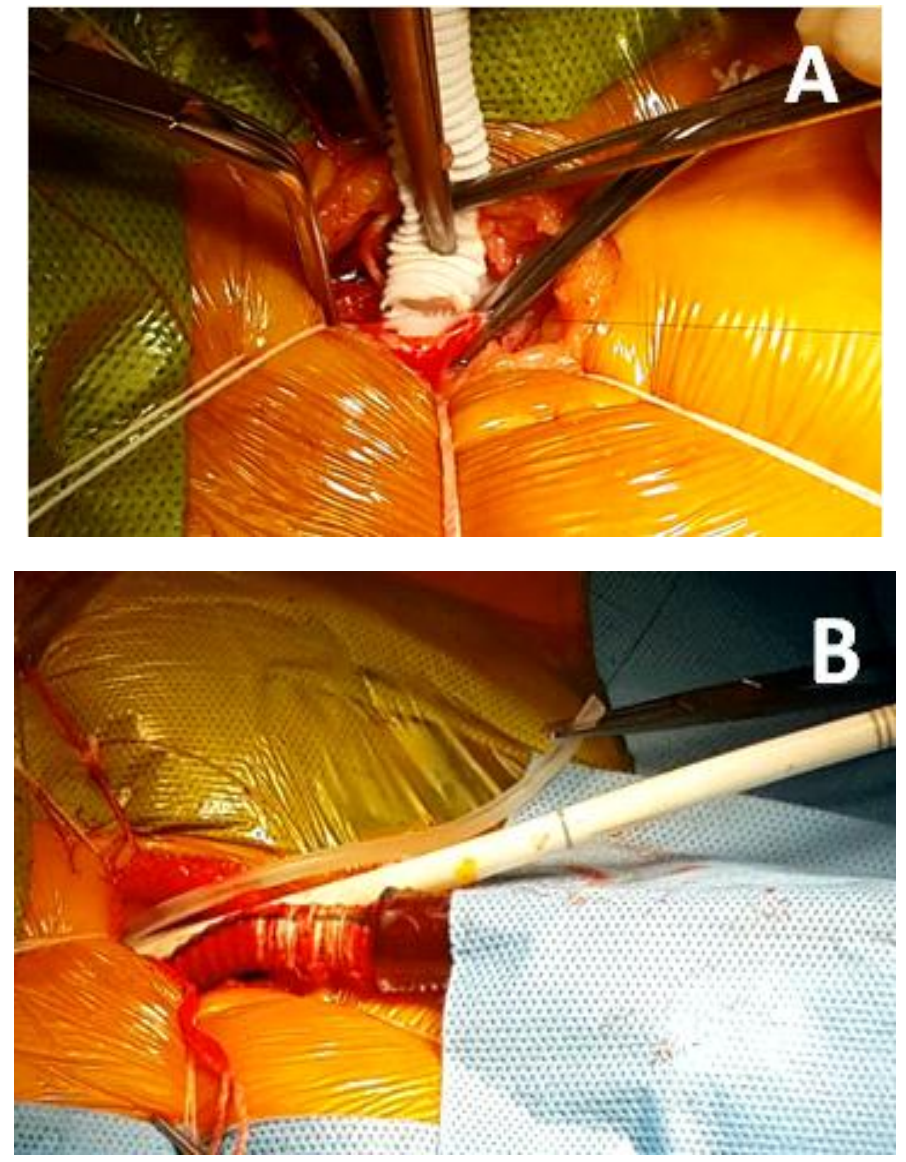

Hình 1: (A) Cannula động mạch đùi được thiết lập gián tiếp qua một đoạn mạch nhân tạo (Dacron hoặc PTFE), và (B) TMC trên và TMC dưới được dẫn lư qua TM cảnh trong phải và TM đùi theo kỹ thuật Seldinger.

Bệnh nhân được đặt tư thế nằm nghiêng trái $30^{\circ}$ (mở ngực phải) hoặc nghiên phải $30^{\circ}$ nếu mở ngực trái, hai tay xuôi theo thân người, đầu nghiên về phía bên trái bộc lộ kim luồn đã được đặt sẵn. Phẫu thuật viên vẽ sẵn đường mổ dài $4-5 \mathrm{~cm}$ trên đường nếp lằn dưới vú (ở người lớn) hoặc dọc theo xương sườn số 5 (ở trẻ nhỏ).

Để thiết lập tuần hoàn ngoại vi chúng tôi tạo một đường rạch dài $2 \mathrm{~cm}$ ngang ở nếp bẹn bên phải, bộc lộ ĐM chung và $\mathrm{TM}$ đùi. Thiết lập đường động mạch một cách gián tiếp vào $\mathrm{DM}$ đùi chung qua một đoạn mạch nhân tạo (Dacron hoặc PTFE). Cannula TMC trên và TMC dưới được đặt qua TM cảnh trong phải và TM đùi bằng phương pháp Sheldinger. Trước khi quyết định mở ngực, chúng tôi test thử đường động mạch bằng cách chạy máy thử, nếu với toàn bộ lưu lượng mà áp lực $Đ \mathrm{M}<200 \mathrm{mmHg}$ thì chấp nhận được. Nếu áp lực đường động mạch tăng quá $200 \mathrm{mmHg}$ thì sẽ quyết định chuyển cưa bán phần xương ức.

Sau khi rạch da theo đường mổ định sẵn, chúng tôi vào khoang màng phổi qua khoang liên sườn 4 . Vén mềm được sử dụng để bảo vệ tổ chức liên kêt, sau đó chúng tôi sử dụng dụng cụ banh ngực nhỏ để mở rộng phẫu trường một chút.Trocar $5 \mathrm{~mm}$ cho đèn nội soi được đặt ở khoang liên sườn 4 đường nách giữa. Sau khi vào đến khoang màng phổi, hệ thống tuần hoàn ngoài cơ thể bắt đầu hoạt động, nhiệt độ thực quản được hạ dần xuống $32^{\circ} \mathrm{C}$, màng tim được mở song song và phía trước so với thần kinh hoành $1.5-2 \mathrm{~cm}$. 


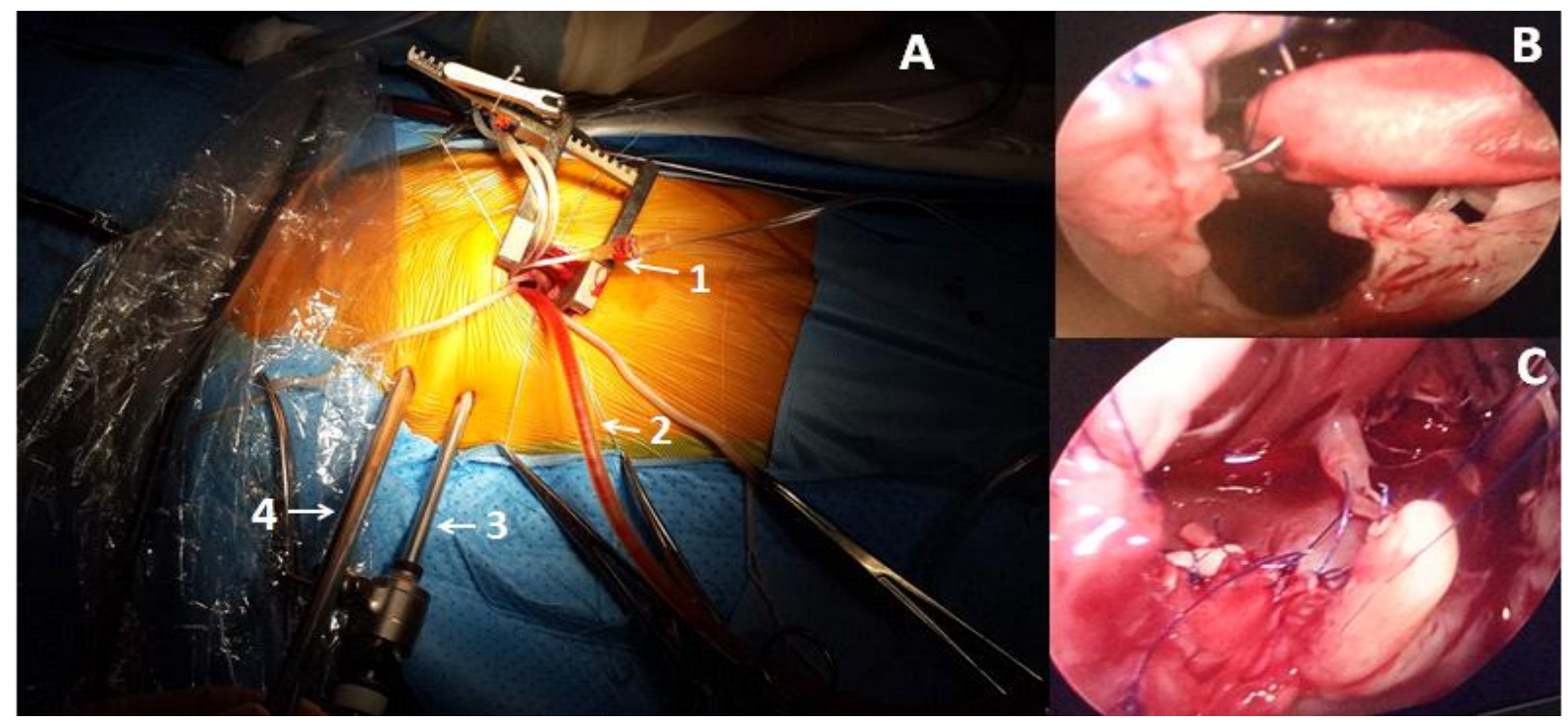

Hình 2: Kỹ thuật của đường mở ngực nhỏ trước bên phải. (A) đường mổ 4-5cm, vào khoang màng phổi qua khoang liên suờn 4, liệt tim xuôi dòng qua gốc ĐMC (1), dẫn lưu tim trái được đặt qua vách liên nhĩ hoặc TMP trên phải (2), Trocar cho camera (3) và clamp Chitwood (4) được đặt trên đường nách giũa; (B) Sư dụng miếng vá nhân tạo để đóng lỗ TLT với đường khâu vắt; (C) Kết thúc quá trình đóng lỗ TLT.

Clamp Chitwood được đặt ở KLS 3 đường nách giữa và được sử dụng để cặp cả ĐMC lên và thân ĐMP. Bảo vệ cơ tim xuôi dòng qua gốc ĐMC sử dụng dung dịch custodiol ${ }^{\circledR}$ HTK.

Với đường mở ngực phải, sử dụng đường mở chéo cho nhĩ phải sau khi đã thắt TMC trên và TMC dưới, dẫn lưu tim trái được đặt qua vách liên nhĩ, toàn bộ dung dịch liệt tim được hút bỏ.Van ba lá thường phải xẻ mép giữa lá trước và lá vách hoặc xẻ chân lá trước dọc theo vòng van để bộc lộ rõ tổn thương. Lỗ thông được đóng bằng miếng vá nhân tạo, khâu vắt.

Với đường mở ngực trái, không thắt $\mathrm{TMC}$ trên và dưới, dẫn lưu tim trái được đặt vào tiểu nhĩ trái, dung dịch liệt tim được hút về máy tim phổi nhân tạo và được lọc trong quá trình phẫu thuật.Thân ĐMP được mở dọc hoặc mở ngang trên vòng van để tiếp cận lỗ thông. Lỗ thông được đóng bằng miếng vá nhân tạo, khâu vắt kết hợp mũi rời từng vị trí.

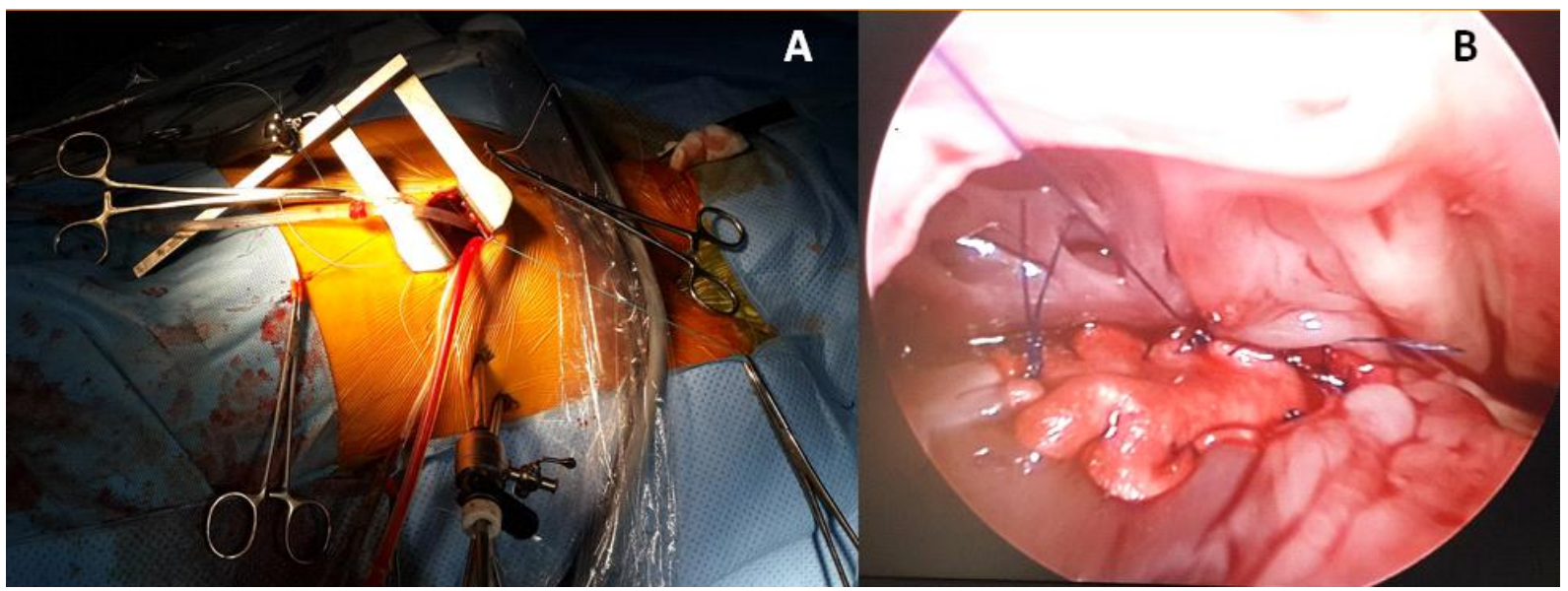

Hình 3: Kỹ thuật mổ cho đường mở ngục nhỏ trước bên trái. (A), đường rạch da dài 4-5cm tại nếp lằn vú, vào khoang màng phổi qua khoang liên suờn 4. Cặp ĐMC và than ĐMP bằng clamp Chitwood. Vá lồ TLT qua van ĐMP. (B), hoàn thành vá lỗ TLT, hai lá van ĐMP nằm sát phía trên miếng vá. 
Tất cả bệnh nhân sau mổ được kiểm tra bằng siêu âm qua thành ngực và siêu âm doppler mạch máu kiểm tra trước khi ra viện.

- Theo dõi sau mổ:

Bệnh nhân được hẹn khám lại sau mổ 1 tháng, 3 tháng, 6 tháng. Bệnh nhân được khám, đánh giá tình trạng sẹo mổ, sự cân đối giữa hai ngực, tình trạng dị cảm quanh vị trí vết mổ ngực và đùi, sự hài lòng của gia đình và bệnh nhân về vị trí và kích thước sẹo mổ.Bệnh nhân được siêu âm tim qua thành ngực và siêu âm doppler mạch kiểm tra.

- Phân tích số liệu:

Số liệu được tính ra trung bình \pm phương sai (S.D.) cho những biến định lượng và tính ra số lượng với tỉ lệ phần trăm cho những biến định tính. Test Mann-Whitney U được sử dụng để xác định sự khác biệt giá trị trung bình của các biến định lượng giữa các nhóm và test Fisher sử dụng cho biến định tính. Giá trị $\mathrm{P}<0.05$ được cho là có ý nghĩa thống kê.

Số liệu được quản lý và phân tích bởi phần mềm SPSS 14.0.

\section{KẾT QUẢ}

Không có trường hợp nào của cả hai nhóm tử vong trong thời gian nằm viện. Trong nhóm mở ngực nhỏ không có trường hợp nào cần mở ngực rộng hoặc chuyển cưa xương ức.

Trong những bệnh nhân TLT quanh màng, thời gian chạy máy và thời gian cặp ĐMC của nhóm mở ngực phải dài hơn so với nhóm mở xương ức $(\mathrm{n}=10)$, lần lượt là $183,4 \pm 54,8$ phút so với $61,2 \pm 17,3$ phút $(\mathrm{p}<0,001)$ và $129 \pm 46,5$ phút so với $38,4 \pm 13,4$ phút $(\mathrm{p}<0,001)$. Tuy vậy, thời gian thở máy, thời gian nằm hồi sức và thời gian nằm viện sau phẫu thuật của hai nhóm tương đương nhau (Bảng 2). Trong nhóm mở ngực phải, không có trường hợp nào có biểu hiện block dẫn truyền nhĩ thất hoặc shunt tồn lưu sau mổ. Mặc dù $6 / 8$ bệnh nhân phải xẻ mép VBLvà 2 trường hợp phải xẻ chân lá trước VBL để bộc lộ lỗ thông, tất cả trường hợp đều có van ba lá không hở hoặc hở nhẹ.

\section{Bảng 2:}

So sánh các thông số trong mổ của dưới nhóm mở ngụcc trước bên phải và dưới nhóm TLT quanh màng có cư toàn bộ xương ức.

\begin{tabular}{|l|c|c|c|}
\hline & $\begin{array}{c}\text { Dưới nhóm mở ngực nhỏ } \\
\text { trước bên phải }(\mathrm{n}=8)\end{array}$ & $\begin{array}{c}\text { Dưới nhóm cưa toàn bộ } \\
\text { xương ức }(\mathrm{n}=10)\end{array}$ & $\mathrm{P}$ \\
\hline Thời gian chạy máy (phút) & $183.4 \pm 54.8$ & $61.2 \pm 17.3$ & $<0.001$ \\
\hline Thời gian cặp ĐMC (phút) & $129.0 \pm 46.5$ & $38.4 \pm 13.4$ & $<0.001$ \\
\hline Thời gian thở máy (giờ) & $3.1 \pm 1.0$ & $2.7 \pm 1.4$ & \multirow{2}{*}{$\begin{array}{c}\text { Sự khác biệt } \\
\text { không có ý } \\
\text { nghĩa thống } \\
\text { kề }\end{array}$} \\
\hline Thời gian nằm hồi sức (giờ) & $21.3 \pm 3.5$ & $10.1 \pm 4.6$ & $\begin{array}{c}\text { keòn } \\
\text { Thời gian nằm viện sau mồ }\end{array}$ \\
\hline
\end{tabular}

Ở những bệnh nhân TLT phần phễu, thời gian chạy máy và thời gian cặp ĐMC của nhóm mở ngực trái dài hơn so với nhóm mở xương ức $(\mathrm{n}=15)$, lần lượt là $147,4 \pm 58,8$ phút so với $43,6 \pm 13,7$ phút $(\mathrm{p}<0,001)$ và $101,9 \pm 43,6$ phút so với $26,9 \pm 12,7$ phút $(\mathrm{p}<0,001)$. Thời gian hồi phục sau mổ của hai nhóm bệnh nhân không có sự khác biệt (Bảng 3). Trong nhóm mở ngực trái, không có trường hợp nào bị hở van ĐMC hoặc van ĐMP sau mổ. 1 trường hợp còn shunt tồn lưu nhỏ đk $2 \mathrm{~mm}$ sau mổ và dòng shunt này mất đi sau theo dõi 6 tháng. 2 trường hợp hẹp nhẹ đường ra thất phải (1 trường hợp hẹp do miếng vá, chênh áp $26 \mathrm{mmHg}$, sau 6 tháng chênh áp còn $9 \mathrm{mmHg} ; 1$ trường hợp hẹp nhẹ trên van ĐMP tại vị trí đường khâu với $\mathrm{P}: 24 \mathrm{mmHg}$ tồn tại sau 5 tháng). 


\section{Bảng 3:}

So sánh các thông số trong mổ của dưới nhóm mở ngục trước bên trái và dưới nhóm TLT phần phễu có cưa toàn bộ xương úc.

\begin{tabular}{|l|c|c|c|}
\hline & $\begin{array}{c}\text { Dưới nhóm mở ngực nhỏ } \\
\text { trước bên trái (n=7) }\end{array}$ & $\begin{array}{c}\text { Dưới nhóm cưa toàn bộ } \\
\text { xương ức }(\mathrm{n}=15)\end{array}$ & $\mathrm{P}$ \\
\hline Thời gian chạy máy (phút) & $147.4 \pm 58.8$ & $43.6 \pm 13.7$ & $<0.001$ \\
\hline Thời gian cặp ĐMC (phút) & $101.9 \pm 43.6$ & $26.9 \pm 12.7$ & $<0.001$ \\
\hline Thời gian thở máy (giờ) & $3.7 \pm 0.5$ & $3.8 \pm 2.1$ & \multirow{2}{*}{$\begin{array}{c}\text { Sự khác biệt } \\
\text { không có ý nghĩa } \\
\text { thống kê }\end{array}$} \\
\hline Thời gian nằm hồi sức (giờ) & $22.9 \pm 4.9$ & $23.6 \pm 6.9$ & $9.5 \pm 3.0$ \\
\hline $\begin{array}{l}\text { Thời gian nằm viện sau mồ } \\
\text { (ngày) }\end{array}$ & $8.1 \pm 1.1$ & & \multirow{2}{*}{}
\end{tabular}

Không có sự khác biệt có ý nghĩa thống kê về thời gian chạy máy và thời gian cặp ĐMC giữa nhóm mở ngực nhỏ trước bên phải và nhóm mở ngực nhỏ trước bên trái với giá trị p lần lượt là 0,29 và 0,27 .

Tất cả bệnh nhân nhóm mở ngực không có biến chứng liên quan tới phẫu thuật và thiết lập tuần hoàn ngoại vi. Một bệnh nhân 6 tuổi bị phù và xuất huyết dưới da ở chân đặt cannula ngay sau mổ, sau 5 ngày tình trạng phù và xuất huyết biến mất.Ở nhóm mở ngực nhỏ, chúng tôi ghi nhận tình trạng giảm đau đáng kể và sớm hơn so với nhóm mở xương ức.

Trong nhóm mở ngực nhỏ, sau thời gian theo dõi (từ 1 tháng đến 1 năm) không có trường hợp nào tử vong muộn. Tất cả bệnh nhân và gia đình hài lòng với tính thẩm mỹ của vết mổ, không tê bì, dị cảm, bệnh nhân tự tin hòa nhập sớm với cuộc sống bình thường.

\section{BÀN LUẬN}

Trong thời đại ngày nay, người bệnh thông liên thất và gia đình không chỉ có nhu cầu điều trị khỏi bệnh mà còn dành nhiều sự quan tâm cho chất lượng cuộc sống của người bệnh trong khoảng thời gian dài sau mổ. Ở người trưởng thành, lỗ thông liên thất thường hạn chế, bệnh nhân không triệu chứng trong khi nhu cầu hòa nhập xã hội cao do đó sẹo mổ xấu và dài nằm ở những vị trí lộ có thể trở thành rào cản vô hình gây cản trở bệnh nhân trong những sinh hoạt hàng ngày. Ở trẻ nhỏ, biến dạng lồng ngực sau mổ tim là nguyên nhân dẫn tới mặc cảm của trẻ khi lớn lên.
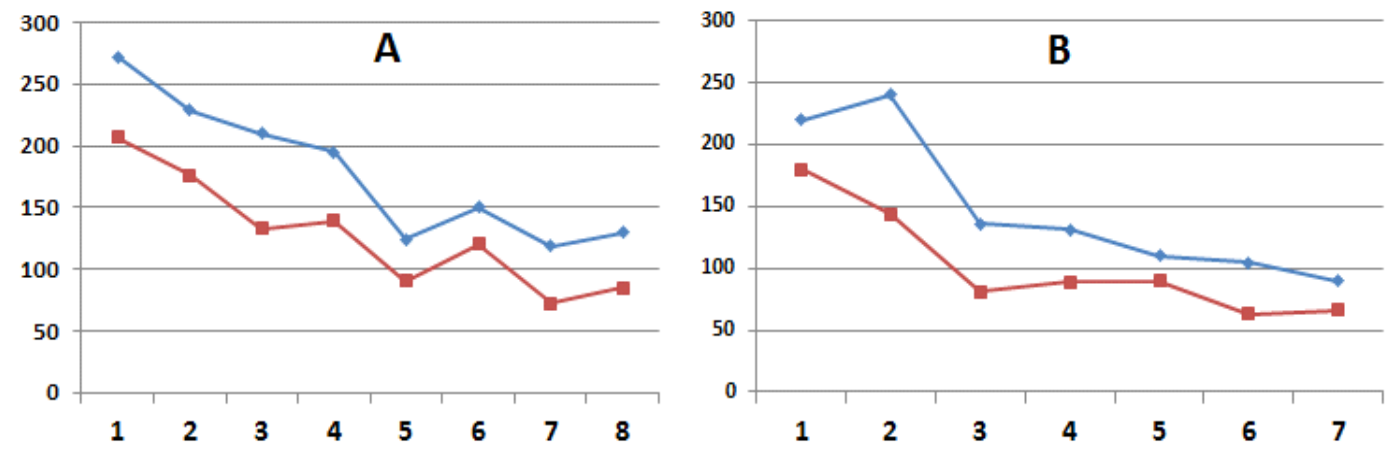

$\rightarrow$ CPB time

$=$-Aortic clamp time

Biểu đồ 1: Thời gian chạy máy và thời gian cặp ĐMC của dưới nhóm đường mở ngục nhỏ trước bên phải (A) và dưới nhóm mở ngục nhỏ truớc bên trái (B). Trục ngang biểu thị bệnh nhân được mổ theo thời gian. Trục dọc là thời gian mổ (phút). 
Về thiết lập tuần hoàn ngoài cơ thể, theoJung, $\mathrm{S}$. H. cùng cộng sự (2010) để phòng những biến chứng liên quan tới bơm máu ngược dòng thì ở những bệnh nhân lớn tuổi phải đánh giá ĐMC xuồng bằng siêu âm qua thực quản hoặc CT scan trước mổ, nếu ĐMC xuống của bệnh nhân có tình trạng xơ vữa mức độ vừa trở lên thì chống chỉ định tuần hoàn ngoài cơ thể ngoại vi [4]. Ma, Z. S. cùng cộng sự. (2011) với kinh nghiệm phẫu thuật 119 trường hợp phẫu thuậtvá TLT nội soi toàn bộ ở trẻ nhỏ đã đưa ra khuyến cáo, nên lựa chọn bệnh nhân $>20 \mathrm{~kg}$, loại ra khỏi nghiên cứu những trường hợp động mạch và tĩnh mạch đùi quá nhỏ (được đánh giá bằng siêu âm mạch máu trước mổ)[5]. Nghiên cứu của chúng tôi thực hiện trên cả nhóm đối tượng người lớn và trẻ nhỏ, bệnh nhân lớn tuổi được siêu âm tim đánh giá tình trạng xơ vữa thành ĐMC xuống, động mạch cảnh và động mạch chi dưới. Với nhóm bệnh nhân trẻ nhỏ, chúng tôi phẫu thuật thành công trên bệnh nhân nhỏ nhất 3 tuổi, $10 \mathrm{~kg}$. Để tránh biến chứng thiếu máu chân khi mổ kéo dài và phòng hẹp động mạch chậu sau mổ chúng tôi đặt cannula động mạch gián tiếp qua đoạn mạch nhân tạo (Dacron hoặc PTFE). Theo dõi sau 6 tháng chúng tôi không gặp trường hợp nào có biểu hiện hẹp mạch chi dưới ngay cả ở những trẻ rất nhỏ.

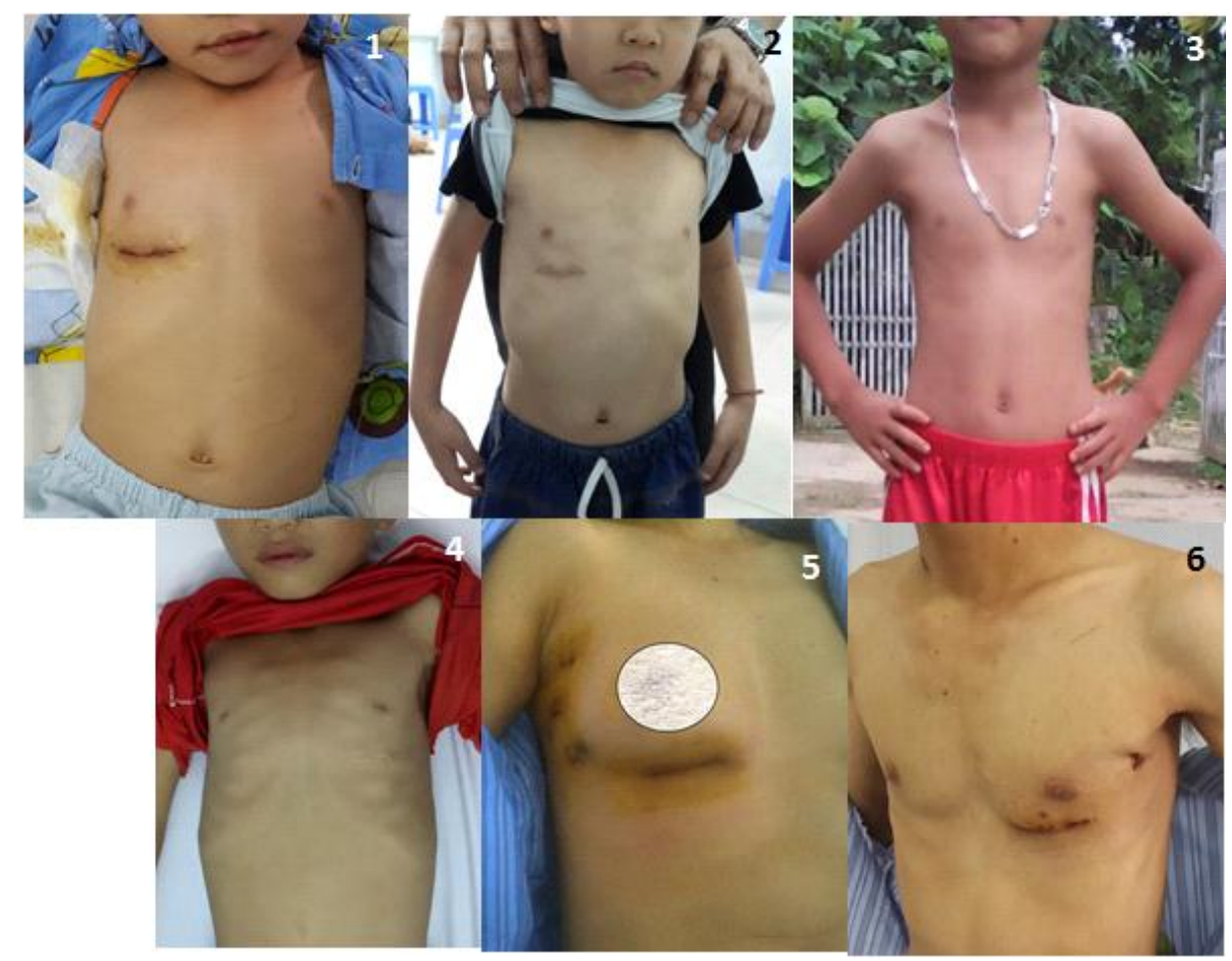

Hình 4: Hình (1) và (2) là hình chụp sẹo mổ của bệnh nhân 6 tuổi ngay sau mổ và khám lại sau mổ 5 tháng; hình (3) là hình chụp sẹo mổ trên ngưc trái của bệnh nhi 6 tuổi khám lại sau mổ 6 tháng; hình (4) sẹo mồ trên ngực trái của bệnh nhi 9 tuổi sau mổ 7 tháng; hình (5) và (6) là sẹo mổ của bệnh nhân TLT người lớn.

Gây mê bằng nội khí quản hai nòng hoặc sử dụng nội khí quản một nòng nhưng thông khí riêng một phổi với tần số thở tăng lên được nhiều tác giả lựa chọn [6-8]. Tuy nhiên Ma, Z. S. cùng cộng sự. (2012) khuyến cáo chỉ nên sử dụng nội khí quản hai nòng ở bệnh nhân $>50$ tuổi trong khi nhiều tác giả ghi nhận tổn thương phổi sau mổ do thông khí đơn độc một
phổi.Hầu hết bệnh nhân của chúng tôi có cân nặng thấp do đó chúng tôi lựa chọn phương pháp gây mê bằng ống nội khí quản một nòng thông khí hai phổi, khi bắt đầu mở ngực cũng là lúc bắt đầu chạy máy do đó thời gian chạy máy của chúng tôi kéo dài.

Nhiều yếu tố có thể ảnh hưởng tới thời gian phẫu thuật, bao gồm: (1) chiều dài đường rạch da, (2) mức 
độ banh xương sườn, (3)đường tiếp cận tổn thương, (4) kinh nghiệm của phẫu thuật viên và (5) mức độ phức tạp của tổn thương. Đường rạch da ngắn hơn $1 \mathrm{~cm}$ và banh xương sườn ít hơn một chút có thể khiến thao tác trở nên khó khăn và kéo dài thời gian phẫu thuật nhiều hơn chúng ta nghĩ.

Lin, P. J. cùng cộng sự (1998) sử dụng đường mổ dọc cạnh ức trái để vá TLT - mặc dù thời gian phẫu thuật ngắn song đây là đường mổ gây tổn thương tuyến vú nhiều và không thẩm mỹ nhất là ở phụ nữ [9].Việc cố gắng đạt sẹo mổ nhỏ, đường mổ khuất vị trí dưới nếp lằn vú khiến chúng tôi chấp nhận thời gian mổ kéo dài và thời gian mổ này chỉ được rút ngắn lại khi phẫu thuật viên có nhiều kinh nghiệm hơn.

Theo Jung, S. H. cùng cộng sự (2010), TLT phần phễu dưới van ĐMC là vị trí không tiếp cận được qua đường mở ngực trái và phải [4]. Tuy vậy Ma, Z. S. cùng cộng sự (2014) báo cáo có thể sửa chữa tất cả các vị trí thông liên thất qua nội soi toàn bộ [7]. Trong nghiên cứu của chúng tôi có 2 bệnh nhân TLT phần phễu dưới van ĐMC được phẫu thuật qua đường mở ngực nhỏ bên phải, quá trình mổ khó khăn do lỗ thông nằm cao và bị tổ chức van ba lá che. Chúng ta có thể lựa chọn đường mổ cưa nửa trên xương ức để thay thế sẽ giúp rút ngắn rất nhiều thời gian phẫu thuật.Trong nhóm mở ngực nhỏ bên trái, 1 bệnh nhân 9 tuổi hẹp nhẹ trên van tại vị trí mở thân ĐMP còn tồn tại tình trạng hẹp sau mổ 5 tháng. Chúng tôi thấy nguyên nhân hẹp do bệnh nhân nhỏ tuổi, thân ĐMP không giãn, sau khi khâu lại sẽ gây hẹp nhẹ. Để tránh hiện tượng này, chúng tôi khuyến cáo nên cân nhắc sử dụng miếng vá để mở rộng thân ĐMP.

\section{KẾT LUẬN}

Chúng tôi thấy rằng đường mở ngực nhỏ trước bên phảihoặc trái là phương pháp phẫu thuật an toàn, hiệu quả trong điều trị bệnh lý TLT đơn thuần ở cả người lớn và trẻ nhỏ. Kết quả tốt cùng với khả năng sửa chữa TLT ở tất cả các vị trí ngay cả ở những bệnh 169-70. nhân nhỏ tuổi khiến phương pháp phẫu thuật này trở thành phương pháp rất hứa hẹn trong tương lai.

\section{TÀI LIẸU THAM KHẢO}

1. Kadner, A., et al., Inferior partial sternotomy for surgical closure of isolated ventricular septal defects in children. Heart Surg Forum, 2004. 7(5): p. E467-70.

2. Nicholson, I.A., et al., Minimal sternotomy approach for congenital heart operations. Ann Thorac Surg, 2001. 71(2): p. 469-72.

3. Nishigaki, K., et al., Minimal access via lower partial sternotomy for congenital heart defects. Asian Cardiovasc Thorac Ann, 2005. 13(1): p. 42-6.

4. Jung, S.H., et al., Right or left anterolateral minithoracotomy for repair of congenital ventricular septal defects in adult patients. Interact Cardiovasc Thorac Surg, 2010. 10(1): p. 22-6.

5. Ma, Z.S., et al., Totally thoracoscopic repair of ventricular septal defect: a short-term clinical observation on safety and feasibility. $\mathrm{J}$ Thorac Cardiovasc Surg, 2011. 142(4): p. 850-4.

6. Ma, Z.S., et al., Thoracoscopic closure of ventricular septal defect in young children: technical challenges and solutions. Eur J Cardiothorac Surg, 2012. 42(6): p. 976-9.

7. Ma, Z.S., et al., Totally thoracoscopic closure of ventricular septal defect without a robotically assisted surgical system: a summary of 119 cases. J Thorac Cardiovasc Surg, 2014. 147(3): p. 863-7.

8. Mishaly, D., P. Ghosh, and S. Preisman, Minimally invasive congenital cardiac surgery through right anterior minithoracotomy approach. Ann Thorac Surg, 2008. 85(3): p. 831-5.

9. Lin, P.J., et al., Minimally invasive cardiac surgical techniques in the closure of ventricular septal defect: an alternative approach. Ann Thorac Surg, 1998. 65(1): p. 165-9; discussion 